\title{
Privatisering, demokrati og magt i de danske kommuner'
}

\begin{abstract}
En af de centrale bestræbelser indenfor „New Public Management“ (NPM) har siden 1980erne været at fremme forskellige former for privatisering i den offentlige sektor. I de senere år er inddragelse af private aktører i de danske kommuners opgavevaretagelse således blevet øget, hvilket gør det vigtigt at undersøge konsekvenserne af denne udvikling. I artiklen her forstås privatisering som anvendelse af private leverandører i opgaveløsningen, og der fokuseres på, hvad privatisering betyder for de lokalpolitiske aktørers magt. Udgangspunktet er en forventning om, at høj grad af privatisering kan have vidtrækkende konsekvenser for fordelingen af den lokalpolitiske magt. Dette belyses empirisk ved en spørgeskemaundersøgelse blandt 896 kommunale chefer. Hovedresultatet er, at de lokalpolitiske aktører generelt har mindre magt i kommuner med højere grad af privatisering, og at den tilbageværende magt er mere centraliseret $i$ disse kommuner.
\end{abstract}

„Many western democracies are currently implementing governance reform and administrative reform without much reflection of its broader democratic ramifications ... If there is anything to be learned from recent administrative and governance reform, it should be that democracy and administration are integrated processes where reform in one process will impact the other." (Pierre 2009, 603)

Brugen af markedsmekanismen er et centralt element i de seneste årtiers offentlige ledelsesreformer. Sammen med tendensen til at lægge vægt på ledelse og på resultatevaluering indenfor den offentlige sektor udgør den en treenighed, der er blevet betegnet „New Public Management“ (NPM) (Christensen \& Laegreid, 2007; Hood, 1991). NPM, forstået som opprioriteringen af en eller flere af disse tre elementer, har siden starten af 1980erne i stigende grad præget den offentlige sektors styringstænkning i en lang række OECDlande, om end betydningen af disse tanker for den offentlige sektors reelle styringspraksis er omdiskuteret og varierer fra land til land.

I samspil med udviklingen i informations- og kommunikationsteknologi (IKT) har NPM-inspirerede organisatoriske innovationer på godt og ondt sat sit præg på den bølge af administrative reformer, der har præget den offentlige sektor i OECD landene generelt og Danmark mere specifikt siden 1980erne (Ejersbo \& Greve, 2005; Hansen, forthcoming 2010). Et af rationalerne for den danske strukturreform var også at øge kommunernes administrative kapacitet til at håndtere kontraktstyring og andre organisatoriske innovationer. Der er ikke tale om en revolution, idet de nye styringsformer 
sameksisterer med og er indlejret i ældre styringsformer, men der er sket væsentlige $o g$ af og til paradoksale og konfliktfyldte omkalfatringer af styringen af den offentlige sektor.

På trods af denne udvikling er den eksisterende viden om tiltagenes konsekvenser ret begrænset. Især relationen mellem NPM-tiltagenes anvendelse og magtfordelingen blandt de politiske aktører er mangelfuld, og det begynder denne artikel at råde bod på $\mathrm{i}$ en analyse af magtfordelingen i det lokale repræsentative demokrati. Magt skal her forstås som en given aktørs indflydelse på kommunens aktiviteter. Mere specifikt undersøges sammenhængen mellem de lokalpolitiske aktørers magt og privatiseringsgraden forstået som det omfang, hvormed kommunerne inddrager private aktører i kommunernes opgavevaretagelse. De lokalpolitisk aktører er først og fremmest politikerne (borgmesteren, økonomiudvalget og de øvrige politikere), men de administrative topchefer og de lokale interessentgrupper indgår også i analysen. Det er således den konkrete empiriske relation mellem to klassiske institutioner i vores samfund, der er i fokus: Marked og demokrati. Spørgsmålet er, om større brug af private leverandører betyder større magt til de lokalpolitiske aktører, eller om det snarere fører til en teknokratisering og udhuling af det lokale demokrati?

Efter en kort drøftelse af litteraturen om privatiseringens rationaler, konsekvenser og organisering formuleres to hypoteser om konsekvenserne af privatiseringsgraden for de lokalpolitiske aktørers magt. Dernæst redegøres for undersøgelsens datagrundlag og anvendte metoder, hvorefter undersøgelsens resultater præsenteres. I forlængelse heraf diskuteres andre mulige fortolkninger af undersøgelsens resultater. Afslutningsvis drages en konklusion, og forskellige implikationer af undersøgelsen diskuteres.

\section{Privatisering, demokrati og magt}

Forestillinger om et frit marked og et repræsentativt demokrati som grundpiller i et moderne samfund er udgangspunktet for den samfundsorden, der udviklede sig i 1800-tallets Europa i kølvandet på den franske og den amerikanske revolution. De er i dag i vidt omfang ,hellige institutioner“ $\mathrm{i}$ den moderne samfundsorden $\mathrm{i}$ den forstand, at målsætninger om et velfungerende demokrati og et frit marked er udgangspunktet for globale fremherskende ideer om det gode samfund (eksempelvis i OECD's og EU's kriterier for medlemskab) (Meyer, Boli, Thomas, \& Ramirez, 1997). Relationerne mellem disse centrale institutioner har været genstand for adskillige analyser i tidens løb (Buchanan \& Tullock, 1962; Hirschman, 1970; Schumpeter, 1942), og særligt Hirschmans analyser af de dynamiske relationer mellem demokratiets „voice“ mekanisme og markedets „exit“ mekanisme er relevante i relation til denne artikels genstandsfelt. 
Artiklen tager sit udgangspunkt i forestillingen om, at brugen af markedsmekanismer i den offentlige forvaltning fører til en udhuling af demokratiet. Der fokuseres på en variant af udhulingstesen, som blev formuleret af Rod Rhodes i kølvandet på Thatcher-årenes mange privatiseringer og omorganiseringer (Rhodes, 1994). Tesen, som udvikles nedenfor, er, at privatisering har konsekvenser for organiseringen af den offentlige forvaltning, og at den ændrede organisering af forvaltningen medfører en betydelig forandring i de lokalpolitiske aktørers magt. Før denne tese uddybes yderligere, vil de næste afsnit imidlertid kort redegøre for de fremherskende rationaler bag privatisering og for tidligere empirisk forskning i privatiseringens konsekvenser.

\section{Privatiseringens rationaler}

Hvad er det for fordele, man forestiller sig at opnå ved øget grad af privatisering? Privatiseringslitteraturen er omfattende og en lang række eksplicitte og implicitte målsætninger er blevet foreslået (Hodge, 2000; Savas 2000). De forskellige målsætninger hænger sammen med, at privatiseringsbegrebet dækker over forskellige fænomener. Hvis man forstår privatisering som konkurrenceudsættelse ved skabelse af kvasi-markeder med konkurrence mellem forskellige leverandører (private såvel som offentlige), så har målsætninger om øget økonomisk effektivitet været fremherskende. Privatisering i den forstand indebærer, at der kommer mere end en leverandør, og det introducerer beslutningsstrukturer baseret på markedets „exit“ mekanisme (Hirschman, 1970). Med exit forstås brugernes mulighed for at skifte leverandør, hvis de er utilfredse med ydelsen. I modsætning hertil står „voice“ mekanismen, som indtil for 2-3 årtier siden var dominerende i den danske offentlige sektor. „Voice“ består i, at brugere og borgere har mulighed for at give deres mening til kende om den offentlige sektors ydelser og på den måde indirekte kan påvirke de offentlige ydelser. Med introduktionen af „exit“ brydes den offentlige sektors monopol på essentielle velfærdsydelser, og den øgede konkurrence forventes at fremme en effektiv opgaveløsning (Varian, 2006). Det er imidlertid sjældent det eneste mål med konkurrenceudsættelse. Som Alam \& Pacher (2000) skriver, kan det også handle om at reducere omkostningerne, udvikle klarere mål, være lydhøre overfor brugerønsker og forbedre ydelseskvaliteten.

I forhold til disse målsætninger er det væsentligt at skelne mellem selve privatiseringen og den eventuelle effekt af valgfriheden for brugerne. Privatisering sker ved, at offentlige opgaver bliver udbudt i åben licitation, og private leverandører vinder retten til at levere (en del af) ydelserne. Hvis der er mere end en aktør (offentlige eller private), der får retten til at levere serviceydelser, betyder det, at brugerne får et valg mellem forskellige leverandører. Det er ikke nogen nødvendig følge af privatisering, idet kommunerne 
også kan vælge at lade en enkelt privat leverandør løse alle opgaverne, men som oftest vælger kommunerne en løsning med flere leverandører. I så fald får brugerne en reel „exit“ mulighed for at „stemme med fødderne“, hvis de er utilfredse, og der kommer et øget pres på serviceudbydernes evne til at tilpasse sig brugernes krav.

\section{Konsekvenser af privatiseringer}

På trods af privatiseringers høje profilering på reformdagsordenen har analyser af privatiseringens konsekvenser været relativt fåtallige, og de har primært fokuseret på økonomiske konsekvenser ( $f x$ omkostningsniveau og produktivitet) på tekniske serviceområder i angelsaksiske lande (Boyne, 1998; Hodge, 2000). Der findes dog enkelte analyser på ikke-tekniske serviceområder (Hansen, 2010; Meier \& O’Toole, 2009). Resultaterne af analyserne er blandede, men generelt lader privatisering ikke til at have den markante positive effekt på produktivitet, som teorierne om konkurrenceudsættelse lægger op til (Dunleavy, Margetts, Bastow, \& Tinkler, 2006). Empiriske analyser af andre typer konsekvenser end de økonomiske er sjældnere (Hodge, 2000). Nogle forskere har analyseret relationen mellem privatisering og korruption (Donahue, 1989; Kobrak, 2002) ud fra en tese om, at korruption kan blive et større problem i privatiseringsregimer. Andre forskere har analyseret relationen mellem kontrol og ansvar (accountability) og privatisering (Gilmour \& Jensen, 1998) ud fra en tese om, at privatisering vil medføre ansvarsforflygtigelse og uklarhed om ansvarsfordelingen mellem de private leverandører og de offentlige købere. Men så vidt vides, og efter søgninger i Web of science og andre databaser er der ingen tidligere empiriske analyser, der fokuserer på privatiseringens konsekvenser for det lokale demokrati og de lokale aktørers magt.

\section{Privatiseringens organisering}

Tesen her er, at når vi i stigende grad privatiserer den kommunale opgaveløsning, så har det konsekvenser for, hvordan indflydelse kan udøves i det lokale demokrati, her forstået som det formelle demokratis repræsentanter. Der er andre former for lokalt demokrati i form af eksempelvis lokalråd og brugerbestyrelser, men her afgrænses analysen til det klassiske repræsentative demokrati med en folkevalgt kommunalbestyrelse, der konstituerer sig med borgmester, økonomiudvalg og stående udvalg. Det er aktørerne i og omkring dette beslutningssystem, der er i fokus. Forventningen er, at privatisering har betydning for, hvordan beslutninger kan træffes, og kommunerne ledes. Sagt meget forenklet forventes privatisering at medføre en magtoverførsel fra det politiske, demokratiske system til dem, der fører forhandlingerne med de private leverandører. Hvis privatiseringen samtidig betyder, at 
der kommer flere end én valgmulighed for brugerne, forventes brugerne også at få øget magt.

Lidt mere nuanceret kræver etableringen af kvasi-markeder på tidligere offentlige monopolområder en tilpasning af den måde, hvorpå der træffes beslutninger i det lokale demokrati. For at sikre lige konkurrence mellem offentlige og private leverandører i udliciteringsprocessen må der formuleres en gennemskuelig juridisk bindende kontrakt (Greve, 2008). Hvis udliciteringsprocessen indebærer konkurrence mellem en kommunal leverandør $o g$ en eller flere private leverandører, må der ligeledes gennemføres en klar opdeling indenfor den kommunale organisation mellem en bestiller (eller myndigheds) enhed og en udfører (eller leverandør) enhed (O'Flynn \& Alford, 2008). Versioner af ekstern kontraktstyring og (hvis der både er private og offentlige leverandører) Bestiller-Udfører Modeller (ofte kaldet BUM) er nødvendige organisatoriske forudsætninger for, at privatisering kan fungere. I den forstand kan man tale om en særlig organisatorisk konfiguration (Mintzberg, 1979), en styringsteknologi (Greve \& Ejersbo, 2010) eller et særligt privatiseringsregime, som må udvikles for at håndtere denne form for privatiseringer. Det er i denne betydning betegnelsen privatiseringsregime bliver brugt i det følgende.

\section{Odysseus og sirenerne}

Because contracting out confines the duty of contractors to the performance of the terms of contracts and confines the right of supervising principals to enforcing the terms of contracts, it rules out the possibility of day-to-day supervision and intervention which is part of the normal practice within bureaucracies and indeed within any organisation of employees serving a common employer (Mulgan, 1997)

Som Odysseus måtte bindes til masten for ikke at lade sig lokke af sirenernes sang, således må kommunalpolitikerne og forvaltningen underlægges en benhård kontraktstyringsdisciplin, hvis privatiseringen skal fungere. Øget privatisering medfører, at forhandling af bindende eksterne kontrakter får en øget betydning i den kommunale opgaveløsning (Greve, 2008). Eksterne kontrakter aftales desuden for et antal år, og indenfor aftaleperioden er kommunalbestyrelsens og forvaltningens rolle reduceret til at kontrollere, om kontrakten overholdes. Borgere, brugere og lokale interesseorganisationer, som i denne periode måtte henvende sig til kommunalpolitikere eller forvaltning med klager eller utilfredshed, må henvises til næste gang, kontrakten forhandles eller til en teknisk juridisk undersøgelse af, om kontrakten er overholdt. Hvis privatiseringen betyder, at der er kommet mere end en leverandør af de offentlige ydelser, har brugerne til gengæld fået mulighed 
for at fravælge en leverandør, de er utilfredse med. Politikerne har derimod ikke så mange muligheder for at påvirke produktionen af de offentlige ydelser i kontraktperioden. Det er derfor denne artikels overordnede tese, at de lokalpolitiske aktører har mindre beslutningskompetence i kommuner, hvor store dele af driften er privatiseret, sammenlignet med kommuner, hvor dette ikke er tilfældet.

\section{$H_{1}$ : Des bøjere grad af privatisering, des mindre grad af magt bar de lokalpolitiske aktørerne.}

Der er også grund til at forvente en anderledes magtfordeling i det kommunalpolitiske system i kommuner med høj grad af privatisering sammenlignet med kommuner med lav grad af privatisering. Hele kontraktforhandlings- og kontrolprocessen, der er knyttet til et privatiseringsregime, kræver nogle juridiske og faglige kompetencer, som de færreste deltidspolitikere er i besiddelse af. Man må derfor forvente, at særligt de menige ,amatørpolitikere“ har mindre magt i et sådant regime. I og med, at interessentgrupper bl.a. udøver indflydelse gennem politikerne (Binderkrantz, 2005), må de også forventes at stå relativt svagere i kommuner med høj grad af privatisering.

Til gengæld kan det forventes, at fuldtidspolitikere som borgmesteren står relativt stærkere. Borgmesteren vil alt andet lige være den enkeltpolitiker, der har bedst information om kontraktstyringsprocessen og står med de ressourcemæssigt bedste muligheder ( $\mathrm{fx}$ i form af tid og bistand fra embedsmændene) for at udøve indflydelse. Andre ledende politikere, såsom de forskellige udvalgsformænd, vil sandsynligvis have mindre magt i kommuner med høj grad af kontraktstyring sammenlignet med kommuner med lav grad af kontraktstyring. Et privatiseringsregime er i reglen ledsaget af et fokus på strammere økonomistyring og deraf følgende centralisering, og principper for kontraktstyring skal behandles i økonomiudvalget. Det betyder, at medlemmerne af økonomiudvalget kan forventes at have større indflydelse i kommuner med høj grad af privatisering sammenlignet med kommuner med lav grad af privatisering.

Påvirkningen af de administrative topchefers relative indflydelse kan gå begge veje. På den ene side er muligheden for at udøve direkte ledelse mere begrænset $\mathrm{i}$ kommuner med høj grad af privatisering, men på den anden side må de administrative topchefer $\mathrm{i}$ kraft af deres professionelle indsigt forventes at være kompetencemæssigt godt klædt på til at øve indflydelse i kontraktstyringsprocessen i disse kommuner. Man kan også forestille sig, at de to effekter neutraliserer hinanden, $\mathrm{g} g$ at de administrative topchefers magt derfor alt $i$ alt er nogenlunde uforandret. Disse overvejelser forer frem til hypotese 2 , som er yderligere specificeret i en række underhypoteser. 
$H_{2}:$ Magten $i$ kommuner med bøj grad af privatisering er mere centraliseret end magten $i$ kommuner med lav grad af privatisering:

$\mathrm{H}_{2}$ a: Borgmesteren bar større magt $i$ kommuner med bøj grad af privatisering, end det er tilfeldet $i$ kommuner med lav grad af privatisering

$\mathrm{H}_{2} b$ : Økonomiudvalget har større magt $i$ i kommuner med bøj grad af privatisering, end det er tilfeldet $i$ kommuner med lav grad af privatisering

$\mathrm{H}_{2}$ : : Administrative topchefer har samme magt $i$ kommuner med høj og lav grad af privatisering

$\mathrm{H}_{2}$ : Politikere, der ikke er medlemmer af økonomiudvalget, har mindre magt $i$ kommuner med bøj grad af privatisering, end det er tilfeldet $i$ kommuner med lav grad af privatisering

$\mathrm{H}_{2}$ e: Lokale interessentgrupper har mindre magt $i$ kommuner med bøj grad af privatisering, end det er tilfeldet $i$ kommuner med lav grad af privatisering

\section{Data og metode}

De anvendte datakilder er dels en spørgeskemaundersøgelse gennemført i oktober-november 2008 og dels en række kommunale nøgletal opgjort af Indenrigsministeriet og Danmarks Statistik. Dermed måles den uafhængige variabel (privatiseringsgrad) med registerdata, mens målingen af den afhængige variabel (de lokalpolitiske aktørers magt) er baseret på en subjektiv vurdering af aktørernes magt foretaget af de kommunale chefer. Disse bruges dermed som informanter om den faktiske magtfordeling, og det medfører visse validitetsproblemer, som dog er mest alvorlige i forhold til vurderingen af deres egen magt (R6 i tabel 1 nedenfor). Denne fejlkilde i målingen kan imidlertid ikke forventes at være korreleret med kommunens privatiseringsgrad, og som det diskuteres nedenfor, tager kontrolvariablene højde for forskelle i respondenternes jobsituation.

Mere specifikt er respondenterne i spørgeskemaundersøgelsen medlemmer af de kommunale chefforeninger: Kommunaldirektørforeningen, Børne- og Kulturchefforeningen, Kommunalteknisk Chefforening, og Foreningen af Socialchefer. Blandt de 1105 medlemmer har 81,1 \% $(\mathrm{n}=896)$ besvaret spørgeskemaet. Herunder 75,5\% $(\mathrm{n}=74)$ af kommunaldirektørerne (KD), $82,7 \%(\mathrm{n}=81)$ af børne- og kulturdirektørerne (BKD), 71,4 \% (n=70) af de tekniske direktører (TD) og 76,5\% $(\mathrm{n}=75)$ af socialdirektørerne (SD) i Danmark. Herudover har 168 andre forvaltningschefer, 407 andre kommunale ledere og 21 respondenter, hvor titlen er ukendt deltaget. Undersøgelsen kan betragtes som rimeligt repræsentativ for de kommunale topchefer i Danmark efter kommunalreformen (Hansen, Jensen, \& Pedersen, 2009).

Indikatorerne på de lokalpolitiske aktørers magt er fra spørgeskemaundersøgelsen. Der er således konstrueret syv mål for de forskellige aktørgruppers grad af indflydelse på kommunens aktiviteter (se tabel 1). Dels et overordnet 
summativt indeks, der skal måle den samlede indflydelse for 14 forskellige aktørkategorier knyttet til det lokale politiske system (R1). Dels seks variable, der måler indflydelsen for henholdsvis borgmesteren (R2), økonomiudvalget (R3), ledende politikere (R4), menige politikere (R5), administrative topchefer (R6), og lokale interessentgrupper (R7). Fire af disse syv variable er konstrueret som summative indeks (se tabel 1) med en rimelig skala pålidelighed (Cronbachs alpha 0,69-0,78).

Tabel 1. Mål for politisk indflydelse (de afhængige variable)

Spørgsmålsformuleringen lød „Du bedes, på baggrund af din erfaring som administrativ chef i kommunen, give din personlige vurdering af, hvor megen indflydelse de følgende aktører har på kommunens aktiviteter. $1=$ ingen indflydelse; ... ;5=stor indflydelse“.

R1 Indflydelse alle politiske aktører. Sammenlagt indeks*, Cronbachs alpha $=0,78$

R2 Borgmesterens indflydelse

R3 Økonomiudvalgets indflydelse

R4 Ledende politikeres indflydelse. Sammenlagt indeks*. Cronbachs alpha $=0,74$

R5 Menige politikeres indflydelse.

R6 Administrative topchefers indflydelse. Sammenlagt indeks*. Cronbachs alpha $=0,69$

R7 Lokale interessent gruppers indflydelse. Sammenlagt indeks*. Cronbachs alpha $=0,76$
1. Borgmesteren; 2. Udvalgsformændene;

3 . Andre formandsposter i kommunalbestyrelsen; 4. Økonomiudvalget; 5. Gruppeformændene; 6 . Menige kommunalbestyrelsesmedlemmer; 7. Forvaltningscheferne; 8. Kommunaldirektøren; 9. Lokale folketingsmedlemmer; 10. Fagforeningsledere; 11. Medierne; 12 . Det private erhvervsliv; 13. Frivillige organisationer; 14. Enkeltsagsgrupper

\section{Borgmesteren}

Økonomiudvalget

Udvalgsformændene; Andre formandsposter i kommunalbestyrelsen; Gruppeformændene.

Menige politikere.

Forvaltningscheferne; Kommunaldirektøren.

Lokale folketingsmedlemmer; Fagforeningsledere; Medierne; Det private erhvervsliv; Frivillige organisationer; Enkeltsagsgrupper

*Tallene for indeks variablene er lagt sammen og divideret med antallet af variable, der indgår i det pågældende indeks

Indikatoren for grad af privatisering (PLI) er hentet fra Indenrigsministeriets nøgletal. Det er PLI for 2007, der er anvendt, således at det er relationen 
mellem privatiseringsgraden i $2007 \mathrm{og}$ de lokale politiske aktørers magt i 2008, der undersøges i modellerne. PLI er beregnet som andelen af kommunernes brug af private leverandører i pct. af den del af kommunernes samlede opgaveløsning, der må varetages af private leverandører (se også appendiks). En score på 100 ville således indikere, at alle opgaver, der ifølge loven må løses af private leverandører, faktisk også løses af disse. En score på 0 ville indikere, at ingen af disse opgaver løses af private leverandører.

Udover indikatoren for privatisering er der anvendt seks kontrolvariable $i$ analyserne, der præsenteres nedenfor. Der er to grupper kontrolvariable. Den første gruppe tager højde for, at respondenterne (de kommunale chefer, der som nævnt anvendes som informanter om magtfordelingen), har forskellige udgangspunkter for deres vurdering af de lokalpolitiske aktørers magt. Herunder er det meget relevant at kontrollere for respondentens stilling, fordi respondenterne vil have forskellige mulighed for at se magtrelationerne udspille sig, alt efter om de er kommunaldirektør eller ej. Deres uddannelse kan også spille ind, og her kontrolleres for, om de har en samfundsvidenskabelig uddannelse eller ej, fordi respondenter med en sådan uddannelse typisk vil have en større teoretisk baggrund for magtvurderingen. Endelig kontrolleres for køn (kvinde eller ej), fordi eksisterende forskning viser, at kvindelige ledere oftere orienterer sig imod de bredere omgivelser frem for imod hierarkiet (Damanpour \& Schneider 2009: 502). Det kan have betydning for deres vurdering af de lokalpolitiske aktørers magt.

Den anden gruppe kontrolvariable tager højde for, at andre karakteristika ved kommunen end privatiseringsgraden kan have betydning for magtfordelingen. Mere specifikt inddrages to variable for kommunestørrelse (mindre end 20.000 indbyggere eller ej; over 100.000 indbyggere eller ej), fordi større kommuner har flere 'menige' politikere, hvilket kan forskyde magtfordelingen mellem disse og andre aktører, samt en variabel, der indikerer kommunens relative velstand (skattegrundlag). Sidstnævnte er taget med for at kontrollere for, at økonomiudvalgsmedlemmer kan tænkes at have større indflydelse i økonomisk trængte kommuner. Herudover er analyserne blevet kontrolleret for en lang række andre variable, som ikke vises i tabellerne. Blandt andet har dummyvariable for, om borgmesteren var fra partiet Venstre eller ej eller fra Socialdemokratiet eller ej, været inddraget, og alle disse analyser viser konsistent, at sammenhængen mellem privatiseringsgrad og de lokalpolitiske aktørers magt ikke ændres. Analyseresultaterne kan dermed siges at være robuste overfor forskellige modelspecifikationer. Deskriptiv statistik for samtlige variable, som indgår i analysen, fremgår af tabel 2 . 
Tabel 2. Deskriptiv statistik for alle inkluderede variable

\begin{tabular}{|c|c|c|c|c|}
\hline & $\begin{array}{l}\text { Gennem- } \\
\text { snit }\end{array}$ & $\begin{array}{l}\text { Standard } \\
\text { afvigelse }\end{array}$ & $\begin{array}{l}\text { Mini- } \\
\text { mum }\end{array}$ & $\begin{array}{l}\text { Maksi- } \\
\text { mum }\end{array}$ \\
\hline R1 Indflydelses indeks alle aktører & 3,37 & 0,42 & 2 & 4,57 \\
\hline R2 Borgmesterens indflydelse & 4,78 & 0,57 & 1 & 5 \\
\hline R3 Økonomiudvalgets indflydelse & 4,42 & 0,74 & 1 & 5 \\
\hline $\begin{array}{l}\text { R4 Ledende politikeres indflydelse } \\
\text { indeks }\end{array}$ & 3,68 & 0,70 & 1 & 5 \\
\hline R5 Menige politikeres indflydelse & 2,67 & 0,69 & 1 & 5 \\
\hline $\begin{array}{l}\text { R6 Administrative topchefers indflydelse } \\
\text { indeks }\end{array}$ & 4,15 & 0,66 & 1 & 5 \\
\hline $\begin{array}{l}\text { R7 Lokale interessent gruppers indfly- } \\
\text { delse indeks }\end{array}$ & 2,64 & 0,56 & 1 & 4,57 \\
\hline F1 Privatleverandør indikator 2007 & 23,29 & 3,21 & 16,1 & 32,8 \\
\hline F2 Kommunaldirektør & 0,07 & 0,25 & 0 & 1 \\
\hline $\begin{array}{l}\text { F3 Længere samfundsvidenskabelig ud- } \\
\text { dannelse }\end{array}$ & 0,23 & 0,42 & 0 & 1 \\
\hline F4 Kvinde & 0,32 & 0,47 & 0 & 1 \\
\hline F5 Under 20.000 indbyggere & 0,03 & 0,17 & 0 & 1 \\
\hline F6 Over 100.000 indbyggere & 0,11 & 0,31 & 0 & 1 \\
\hline $\begin{array}{l}\text { F7 Kommunens skattegrundlag (vel- } \\
\text { standsindikator) }\end{array}$ & 143.910 & 26.836 & 115.004 & 263.523 \\
\hline
\end{tabular}

$\mathrm{R}=$ Respons variable (afhængige variable); $\mathrm{F}=$ Forklarende variable (uafhængige variable)

Tabel 2 viser, hvordan de kommunale ledere i gennemsnit vurderer forskellige aktørers politiske indflydelse i kommunen (R1-7). Ikke overraskende vurderes borgmesterens indflydelse klart højest $(4,78)$ efterfulgt af økonomiudvalget $(4,42)$, de administrative topchefer $(4,15)$, ledende politikere $(3,68)$, menige politikere $(2,67)$ og lokale interessentgrupper $(2,64)$. Statistikken for privatleverandørindikatoren $(\mathrm{F} 1)$ viser, at mellem $16,1 \% \mathrm{og}$ $32,8 \%$ af opgaverne var konteret som privatiseret i 2007, og at gennemsnittet var $23,39 \%$. Herudover fremgår det, at $7 \%$ af respondenterne er kommunaldirektører (F2), at $23 \%$ har en samfundsvidenskabelig uddannelse $(\mathrm{F} 3)$, at $32 \%$ er kvinder (F4), at $3 \%$ arbejder i kommuner med mindre end 20.000 indbyggere (F5), at $11 \%$ arbejder i kommuner med over 100.000 
indbyggere (F6), og at det gennemsnitlige skattegrundlag i 2007 (F7) var $143.910 \mathrm{kr}$.

\section{Resultater}

I tabel 3 præsenteres de bivariate korrelationer mellem de variable, der indgår $i$ analysen. Mest interessant er privatleverandørindikatorens (F1) korrelation med indflydelsesindikatorerne (R1-R7). Med undtagelse af korrelationen med borgmesterens vurderede indflydelse (R2) er samtlige korrelationer mellem magt-målene og graden af privatisering negative, og korrelationerne er statistisk signifikante $(\mathrm{p}<0,05)$ for alle aktørgruppernes indflydelse $(\mathrm{R} 1)$, indekset for ledende politikeres indflydelse (R4), menige politikeres indflydelse (R5), indekset for administrative topchefers indflydelse (R6) og indekset for lokale interessentgruppers indflydelse (R7). Korrelationerne for borgmesterens indflydelse (R2) og økonomiudvalgets indflydelse (R3) er ikke signifikante. Før vi kan udtale os om hypoteserne, skal sammenhængene imidlertid efterprøves i multiple regressioner med inddragelse af de relevante kontrolvariable.

I tabel 4 vises OLS regressioner, fordi mere avancerede analyser har vist, at dette er uproblematisk, selvom de afhængige variable ikke kan antage værdier under 1 eller over 5 . Alle modellerne er således blevet afprøvet i Tobit regressionsanalyse med dobbeltsidet censurering på minimum og maksimum. Denne analyse er specielt relevant i denne undersøgelse, fordi nogle af de afhængige variable (særligt vurderingen af borgmesterens magt) er temmelig skæv i den forstand, at mange vurderer denne magt meget højt (se tabel 2). Gennemsnitter er således tæt på den absolutte maksimumværdi. Men eftersom resultatet var det samme, hvad angår relationen mellem privatisering og magt, præsenteres de mere enkle OLS regressioner.

Relationerne mellem grad af privatisering (F1) og indikatorerne for politisk indflydelse (model R1-R7) viser samme tendens i de multivariate analyser som i de bivariate analyser, om end styrken af sammenhængene har ændret sig lidt. Den multivariate analyse tyder således på, at det er de menige politikere, hvor den negative forskel $\mathrm{i}$ indflydelse er størst $\mathrm{i}$ sammenligningen mellem kommuner med hhv. høj og lav privatiseringsgrad (model R5). Den multivariate analyse indikerer således støtte til hypotesen om, at des højere grad af privatisering, des mindre magt har de lokalpolitiske aktører (H1). Også forventningen om, at andre ledende politikere (model R4), menige politikere (model R5) og lokale interessentgrupper (model R7) vil have mindre indflydelse, finder støtte i den multivariate analyse. Derimod kan forventningerne om, at borgmester (model R2) og økonomiudvalg (model R3) vil have større indflydelse, des højere grad af privatisering, ikke bekræftes. Disse to aktørkategoriers indflydelse er som de eneste ikke signifikant relateret til privatiseringsgraden. Heller ikke forventningen om, at administrative topchefer 


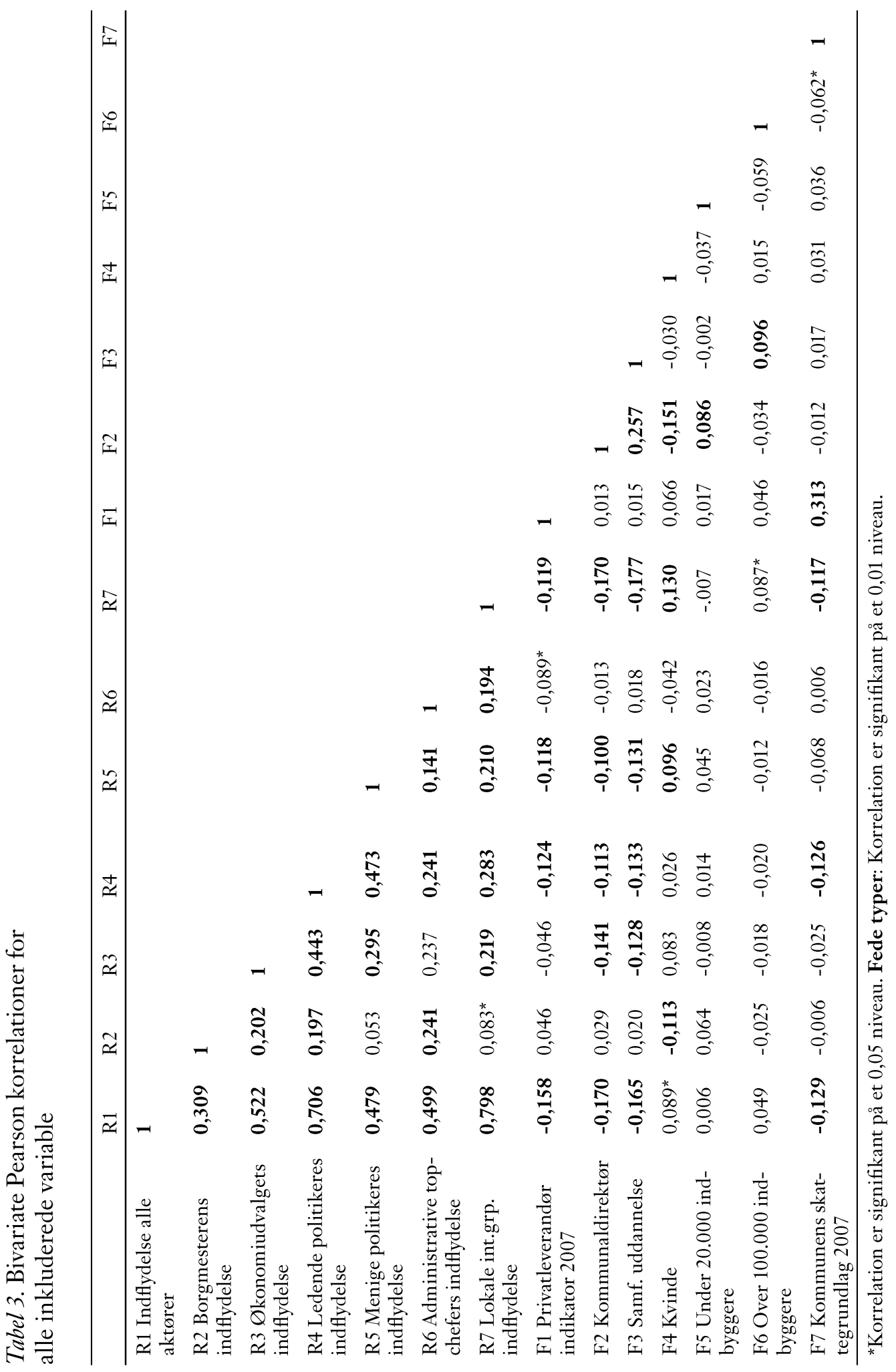




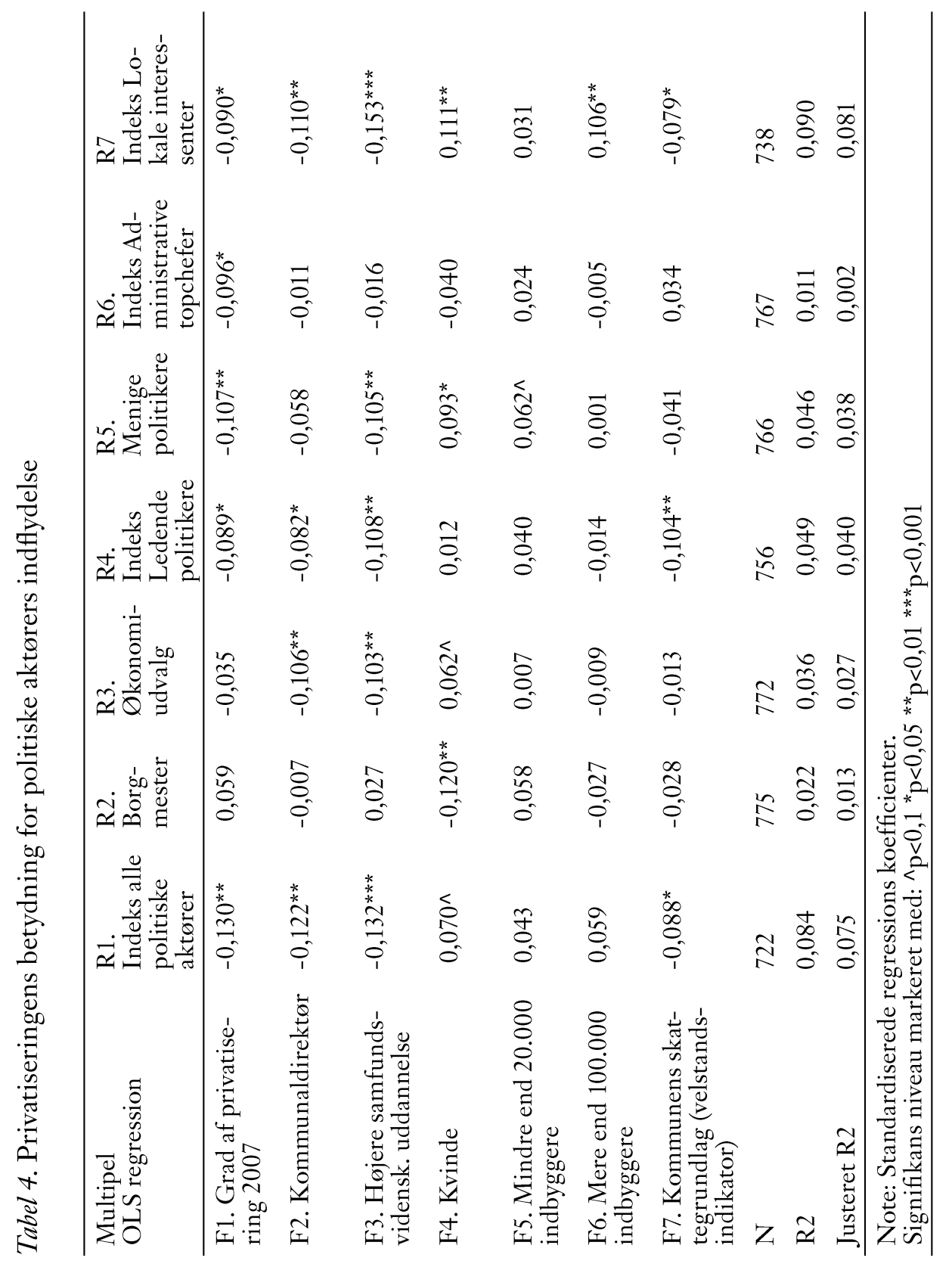


vil have uændret indflydelse (H2b), kan bekræftes (model R6). De administrative chefers indflydelse er signifikant negativt relateret til privatiseringsgrad. I og med, at indflydelsen for alle aktørgrupper (udover borgmesteren og økonomiudvalget) er signifikant negativt relateret til privatisering, indikerer resultaterne dog støtte til den overordnede forventning i hypotese $2 \mathrm{om}$, at højere grad af privatisering hænger sammen med centralisering af indflydelsen i det lokalpolitiske system. Tabel 5 (nedenfor) opsummerer, hvordan resultaterne forholder sig til hypoteser og underhypoteser. Som det sidste skal det bemærkes, at de syv modellers forklaringsgrad ikke er særligt høj, idet $\mathrm{R}^{2}$ varierer mellem 0,09 (model R7) og 0,011 (model R6).

Tabel 5. Oversigt over hypoteser og delhypoteser og deres status i forhold til accept/afvisning

\begin{tabular}{lll}
\hline $\mathbf{H}_{1}$ & $\begin{array}{l}\text { Des højere grad af privatisering, des mindre } \\
\text { grad af magt har aktørerne i det lokale demo- } \\
\text { krati. }\end{array}$ & Accepteret \\
$\mathrm{H}_{2}$ & $\begin{array}{l}\text { Magten i kommuner med høj grad af priva- } \\
\text { tisering er mere centraliseret end magten i } \\
\text { kommuner med lav grad af centralisering }\end{array}$ & $\begin{array}{l}\text { Delvist accepteret } \\
\text { (med forbehold pga. } \\
\text { afvisning af } \mathrm{H}_{2} \mathrm{a}, \mathrm{H}_{2} \mathrm{~b} \\
\text { og H} \mathrm{c} \text { ) }\end{array}$ \\
$\mathrm{H}_{2} \mathrm{a}$ & $\begin{array}{l}\text { Borgmesteren har større magt i kommuner med } \\
\text { høj grad af privatisering, end det er tilfældet i } \\
\text { kommuner med lav grad af privatisering }\end{array}$ & $\begin{array}{l}\text { Afvist } \\
\text { (ingen sammenhæng) }\end{array}$ \\
$\mathrm{H}_{2} \mathrm{~b} \quad \begin{array}{l}\text { Økonomiudvalget har større magt i kommuner } \\
\text { med høj grad af privatisering, end det er tilfældet i } \\
\text { kommuner med lav grad af privatisering }\end{array}$ & $\begin{array}{l}\text { Afvist } \\
\text { (ingen sammenhæng) }\end{array}$ \\
$\mathrm{H}_{2} \mathrm{c} \quad \begin{array}{l}\text { Administrative topchefer har samme magt i kom- } \\
\text { muner med høj og lav grad af privatisering }\end{array}$ & $\begin{array}{l}\text { Afvist (negativ } \\
\text { sammenhæng) }\end{array}$ \\
$\mathrm{H}_{2} \mathrm{~d}$ & $\begin{array}{l}\text { Politikere, der ikke medlemmer af økonomiudval- } \\
\text { get, har mindre magt i kommuner med høj grad } \\
\text { af privatisering, end det er tilfældet i kommuner } \\
\text { med lav grad af privatisering }\end{array}$ & Accepteret \\
$\mathrm{H}_{2} \mathrm{e}$ & $\begin{array}{l}\text { Lokale interessentgrupper har mindre magt i } \\
\text { kommuner med høj grad af privatisering, end det } \\
\text { er tilfældet i kommuner med lav grad af privati- } \\
\text { sering }\end{array}$ & Accepteret \\
\hline
\end{tabular}




\section{Diskussion}

Overordnet kan resultaterne af de empiriske analyser fortolkes som en bekræftelse af de generelle forventninger, som blev opstillet i hypotese 1 og 2 . Graden af privatisering i kommunerne er signifikant negativt relateret til de kommunale lederes vurdering af de fleste lokale politiske aktørers magt. De to overraskelser er, at vurderingerne af borgmesterens og økonomiudvalgets magt ikke er signifikant relateret til privatiseringsgrad, og at der er en negativ sammenhæng mellem privatiseringsgraden og de kommunale topchefers magt.

For borgmesteren og økonomiudvalget er en nærliggende fortolkning, at den øgede magt, disse to aktørgrupper teoretisk set har som følge af en mere centraliseret beslutningsstruktur under et privatiseringsregime, modvirkes af den generelle tendens til, at det lokale repræsentative demokrati svækkes, når der er en høj grad af privatisering.

En tilsvarende fortolkning kan anlægges på den negative relation, der er fundet mellem vurderingen af de kommunale topchefers magt og privatisering. Hypotesen var, at de administrative topchefers magt alt $i$ alt ville være upåvirket af privatiseringsgraden. Argumentet var, at selvom topchefer i kommuner med høj grad af privatisering har ringere mulighed for direkte intervention pga. kontraktrelationen, så opvejes dette af, at de har gode muligheder for at påvirke kontrakterne pga. deres professionelle ekspertise og deres funktion som designer, kontrollant og fortolker af kontraktstyringssystemet. Som nævnt kan privatisering give større magt til brugerne, hvis introduktionen af privat aktører giver brugerne valgfrihed mellem flere leverandører, og det er muligt, at denne øgede magt hos brugerne reducerer topcheferne muligheder for at påvirke serviceproduktionen, fordi leverandørerne orienterer sig mod brugernes behov snarere end de kommunale chefers ønsker. Der kan også tænkes, at direkte kommandomagt opleves som mere magtfuldt end indirekte ekspertmagt. Dette kan imidlertid ikke afklares uden videre undersøgelser, fordi undersøgelsen her ikke indeholder mål for brugernes indflydelse.

Samlet set viser undersøgelsen for det første, at de lokalpolitiske aktører generelt har mindre magt $i$ kommuner med høj grad af privatisering end i kommuner med lav grad af privatisering. Det betyder dog ikke nødvendigvis, at borgerne har mindre magt. Især hvis borgerne er brugere af en given ydelse, vil de kunne påvirke ydelsesproduktionen, hvis privatiseringen er koblet til valgfrihed mellem forskellige leverandører. Såfremt utilfredse brugere kan vælge en anden leverandør, styrker det i Hirschmans terminologi exit muligheden. I denne sammenhæng kan det imidlertid være sket på bekostning af voice muligheden, idet resultaterne kunne tyde på, at nytten af at klage til det lokale kommunalbestyrelsesmedlem er mindre i kommuner 
med høj grad af privatisering. Man kan lidt slagordspræget sige, at borgerdemokratiet er mindre i kommuner med høj grad af privatisering, mens brugerdemokratiet er større.

For det andet indikerer undersøgelsen, at de lokalpolitiske aktørers magt er mere centraliseret i kommuner med høj grad af privatisering. Magten er i disse kommuner mere koncentreret hos borgmesteren og i økonomiudvalget. De har ikke større indflydelse end deres borgmester/økonomiudvalgskolleger i kommuner med lav grad af privatisering, men de øvrige aktørgrupper i kommunerne med høj grad af privatisering har markant mindre magt. Man kan diskutere, om det udgør et problem. Det rejser i hvert fald spørgsmålet om, hvad de mange menige politikeres rolle i den lokale demokratiske proces skal være. Ombudsmandsrollen kan således være sværere at udøve i et kontraktstyringsregime, og den juridiske og økonomiske ekspertise, der typisk kræves for at øve indflydelse i kontraktstyringsprocessen, er sjælden hos deltidspolitikere.

Afslutningsvis skal det bemærkes, at modellernes forklaringsgrad er meget lav. Det indikerer, at der er variable, der ikke er inddraget, der er væsentlige for at forstå forskelle i indflydelse. Det ændrer imidlertid ikke på denne artikels konklusioner, så længe disse variable ikke både påvirker privatiseringsgraden og de lokalpolitiske aktørers indflydelse. Endelig skal det understreges, at der er tale om kommunale chefers vurdering af lokale politiske aktørers indflydelse. Om disse resultater holder med brug af andre typer af data og indikatorer, må fremtidige forskningsprojekter vise.

På trods af analysens begrænsninger har artiklen en klar samfundsmæssig relevans for spørgsmålet om kommunernes rolle i den offentlige sektor. Denne klassiske problemstilling indenfor kommunalforskningslitteraturen (Judge, Stoker, \& Wolman, 1995) behandles også i Greves og Ejersbos artikel i dette temanummer (Greve \& Ejersbo, 2010). Skal kommunerne først og fremmest fungere som effektive implementeringsorganer for statslige beslutninger, eller er kommunernes rolle primært at være bærere af og repræsentanter for et levende lokalt demokrati (Goldsmith, Judge, Stoker, \& Wolman, 1995)? Hvordan skal balancen mellem den nationale parlamentariske styringskæde (Olsen, 1978) og den lokale ditto være? I forhold til disse spørgsmål bidrager artiklen med et budskab om, at tiltag som privatisering kan have betydning for de lokalpolitiske aktører magt og dermed også for, hvem der får hvad i kommunerne. Disse - utilsigtede? - konsekvenser bør medtænkes, når man i fremtiden overvejer at indføre lignende tiltag.

\section{Konklusion}

Privatisering af kommunernes aktiviteter har været en væsentlig bestræbelse i regeringens aftaler med KL de senere år. Det har i såvel Danmark som 
internationalt i årtier været en central tendens i offentlige ledelsesreformer i OECD landene - især i de angelsaksiske lande. Det betyder, at vi i stigende grad kan begynde at analysere såvel tilsigtede som utilsigtede konsekvenser af denne privatisering. Tidligere analyser har primært fokuseret på økonomisk performance på organisationsniveau. De er først og fremmest gennemført i USA og andre Angelsaksiske lande, og de har endvidere primært fokuseret på tekniske ydelser med renovationsområdet som topscorer.

Denne artikel har fokuseret på en konsekvens, som ikke har været belyst i tidligere undersøgelser. Hvilken betydning har privatiseringsgrad for udøvelse af indflydelse i det lokale repræsentative demokrati? Den empiriske undersøgelse giver støtte til teoretiske argumenter for, at de lokalpolitiske aktører generelt har mindre magt i kommuner med høj grad af privatisering sammenlignet med kommuner med mindre grad af privatisering, og at den tilbageværende lokalpolitiske magt er mere centraliseret i førstnævnte kommuner.

\section{Noter}

1 Tidligere versioner af denne artikel har været præsenteret på ECPR konferencen i Potsdam september 2009 og på forvaltningsgruppens seminar på institut for Statskundskab i Århus i november 2009. Jeg vil gerne takke deltagerne herfra for gode konstruktive kommentarer. Endvidere vil jeg gerne takke Lotte Bøgh Andersen, Vibeke Normann Andersen, Poul Erik Mouritzen og en anonym reviewer for gode forslag til forbedringer.

\section{Litteratur}

Binderkrantz, A., 2005. „Organisationerne og indflydelsen: Hvordan interesseorganisationer søger indflydelse på offentlig politik“", politica, 37(1), 76-94.

Boyne, G. A. (1998). Public Choice Theory and Local Government : A Comparative Analysis of the UK and the USA. Basingstoke: Macmillan.

Buchanan, J. M., \& Tullock, G. (1962). The Calculus of Consent. Logical Foundations of Constitutional Democracy: Ann Arbor: University of Michigan Press.

Christensen, T., \& Laegreid, P. (Eds.). (2007). Transcending new public management: the transformation of public sector reforms Aldershot: Ashgate.

Damanpour, F. \& M. Schneider (2009). „Characteristics of Innovation and Innovation Adoption in Public Organizations: Assessing the Role of Managers.“ Fournal of Public Administration Research \& Theory 19(3): 495-522.

Donahue, J. D. (1989). The Privatization Decision: Public Ends, Private Means. New York: Basic Books.

Dunleavy, P., Margetts, H., Bastow, S., \& Tinkler, J. (2006). New public management is dead - long live digital-era governance. Fournal of Public Administration Research and Theory, 16(3), 467-494. 
Ejersbo, N., \& Greve, C. (2005). Moderniseringen af den offentlige sektor. Copenhagen: Børsens Forlag.

Gilmour, R. S., \& Jensen, L. S. (1998). Reinventing government accountability: Public functions, privatization, and the meaning of „state action“. Public Administration Review, $58(3), 247-258$.

Goldsmith, M., Judge, D., Stoker, G., \& Wolman, H. (1995). Autonomy and city limits. In Theories of Urban Politics (pp. 228-252). London: Sage.

Greve, C. (2008). Contracting for Public Services. London: Routledge.

Greve, C., \& Ejersbo, N. (2010). Kontraktstyring i kommunerne. Politica, 2.

Hansen, M. B. (2010). Marketization and Economic Performance. Competitive Tendering in the Social Sector. Public Management Review, 12(2), 255-274.

Hansen, M. B. (forthcoming 2010). Antecedents of Organizational Innovation. The Diffusion of New Public Management into Danish Local Government. Public Administration.

Hansen, M. B., Jensen, C. P., \& Pedersen, J. T. (2009). Kommunernes administrative lederskab efter kommunalreformen. Spørgeskemaundersøgelse til medlemmerne af de kommunale chefforeninger, efteråret 2008 (No. 24). Odense: Syddansk Universitet, Institut for Statskundskab.

Hirschman, A. O. (1970). Exit, Voice, and Loyalty. Cambridge: Harvard University Press.

Hodge, G. (2000). Privatization. An International Review of Performance. Boulder: Westview Press.

Hood, C. (1991). A Public Management for All Seasons. Public Administration, 69(1), 3-19.

Judge, D., Stoker, G., \& Wolman, H. (1995). Theories of Urban Politics. London: SAGE Publications.

Kobrak, P. (2002). Cozy Politics: political parties, campaign finance, and compromised governance. Boulder, Colorado: Lynne Riener Publishers.

Meier, K. J., \& O'Toole, L. J. (2009). The Proverbs of New Public Management Lessons From an Evidence-Based Research Agenda. American Review of Public Administration, 39(1), 4-22.

Meyer, J. W., Boli, J., Thomas, G. M., \& Ramirez, F. O. (1997). World society and the nation-state. American Fournal of Sociology, 103(1), 144-181.

Mintzberg, H. (1979). Structuring of organizations. Englewood Cliffs: Prentice Hall.

Mulgan, R. (1997). Contracting out and accountability. Australian Fournal of Public Administration, 56(4), 106-116.

O'Flynn, J., \& Alford, J. (2008). The separation/specification dilemma in contracting: The local government experience in Victoria. Public Administration, 86(1), 205-224.

Olsen, J. P. (1978). Politisk Organisering. Oslo: Universitetsforlaget.

Pierre, J. (2009). Reinventing governance, reinventing democracy? Policy and Politics, 37(4), 591-609.

Rhodes, R. A. W. (1994). The Hollowing Out of the State - The Changing Nature of the Public-Service in Britain. Political Quarterly, 65(2), 138-151.

Savas , E. S. (2000). Privatization and public-private partnerships. New York: Chatham House.

Schumpeter, J. A. (1942). Capitalism, Socialism and Democracy. New York: Harper \& Row.

Varian, H. R. (2006). Intermediate microeconomics: a modern approach (7 ed.). New York: W.W. Norton \& Co. 


\section{Appendiks: Definitioner af forklarende (uafhængige) variable som er inkluderet $i$ analysen}

F1. Privatleverandør indikator 2007 Indikatoren opgør kommunens andel af private leverandører i procent af de udgifter til private leverandører, der må afholdes ifølge lovgivning. Baseret på regnskabstal. Se nærmere definition på indenrigsministeriets hjemmeside.

F2. Kommunaldirektør $1=$ Kommunaldirektør; $0=$ Anden slags leder

F3. Lang uddannelse i samfundsvidenskab (jura, økonomi, statskundskab, mv.)

1=Lang uddannelse i samfundsvidenskab $0=$ Ingen lang uddannelse i samfundsvidenskab

F4. Kvinde $1=$ Kvinde; $0=$ Mand

F5. Kommuner med 20.000 indbyggere eller mindre

$1=20.000$ eller færre indbyggere

$0=$ Mere end 20.000 indbyggere

F6. Kommuner med 100.000 indbyggere eller mere $1=100.000$ eller flere indbyggere $0=$ Mindre end 100.000 indbyggere

F7. Kommunens skatteudskrivningsgrundlag per indbygger 2007

Kommunens budgetterede udskrivningsgrundlag, inkl. ligningsprovenu, tillagt en andel af de afgiftspligtige grundværdier og et beregnet grundlag for ejendomsværdiskat pr. indbygger pr. 1 . januar. 